\title{
ANALISIS PENGARUH INFORMASI PROSPEKTUS PERUSAHAAN TERHADAP INITIAL RETURN SAHAM PADA PASAR PERDANA DI BURSA EFEK INDONESIA
}

\author{
Afriyeni, Doni Marlius \\ Akademi Keuangan dan Perbankan Padang \\ afriyeni@akbpstie.ac.id
}

\begin{abstract}
This research investigates three variable of prospectus report that being Signalling Concequences to initial return stock at Initial Public Offering. These variable are Profitabily, Financial Leverage and Liquidity. The sample took in the present research consists of 35 firms, which have been listed at Indonesia Stock Exchange since 2002 until 2006 years. The financial report data took as time as public offering. The $t$ and $F$ tests in multiple regression models are used to test hypotheses. Research finding show that: Liquidy at financial report are statistically significant to Signalling Concequences Initial Return. Second, other financial as Profitability and Financial Leverage are statistically no significant to Signalling Concequences initial return stock. This results indicates that investor think liquidity is superior to predict initial return stock at Initial Public Offering.
\end{abstract}

Keywords: Signalling Concequences, Initial Return,Initial Public Offering

\section{PENDAHULUAN}

Sebelum menawarkan saham di pasar primer (perdana), perusahaan emiten sebelumnya akan mengeluarkan informasi mengenai perusahaan secara detail atau yang sering disebut prospektus. Prospektus berfungsi untuk memberikan informasi mengenai kondisi perusahaan kepada para calon investor, sehingga dengan adanya informasi tersebut, maka investor akan bisa mengetahui prospek perusahaan di masa datang, dan selanjutnya tertarik untuk membeli sekuritas yang diterbitkan oleh emiten apabila informasi yang disampaikan memberikan sinyal positif bagi investor dalam memenuhi tujuan investasinya..

Teori pensignalan kurang mendapat perhatian dalam penelitian empiris di Indonesia dibanding teori keagenan, teori urutan pematukan (pecking order theory) dan teori aliran kas bebas (free cash flow theory). Demikian juga penelitian tentang pensignalan lebih banyak mengacu pada bentuk studi peristiwa. Studi peristiwa menekankan pada respon atau reaksi pasar seketika terhadap informasi yang umumnya menggunakan basis data harian. Sementara itu, penelitian pensignalan yang menggunakan basis data tahunan kurang mendapat perhatian. Dalam studi empiris Susilowati (2006), dengan menggunakan basis data tahunan menunjukkan bahwa kewajiban finansial dan kewajiban operasional sebagai signal subtitusi maupun signal komplemen dalam keputusan pendanaan.

Initial Public Offering (IPO) atau penawaran saham perdana yang dilakukan perusahaan emiten merupakan salah satu cara perusahaan mendapatkan dana dari masyarakat. IPO adalah langkah awal untuk menentukan kelangsungan hidup perusahaan 
publik. Harga saham yang ditawarkan pada saat melakukan IPO merupakan faktor penting yang menentukan berapa besar jumlah (emiten).

Jumlah dana yang diterima emiten adalah perkalian antara jumlah lembar saham yang ditawarkan dengan harga per saham. Ada dua kemungkinan yang terjadi terhadap harga saham setelah penawaran. Pertama adalah harga saham perdana lebih besar dari harga yang terjadi pada saat saham tersebut mulai diperdagangkan disebut sebagai overpricing dan yang kedua disebut under-pricing yaitu kondisi yang terjadi jika harga saham perdana lebih kecil dari harga yang terjadi pada saat saham tersebut mulai diperdagangkan di pasar sekunder (Firth dan Smith, 1992). Bila underpricing terjadi, maka investor berkesem-patan memperoleh abnormal return berupa initial return positif. Penelitian yang dilakukan Aggrawal, et. al (1993) menyimpulkan bahwa IPO dalam jangka pendek menunjukan terjadinya underpricing, tetapi dalam jangka panjang terjadi return yang negatif. Underpricing ini di satu pihak menguntungkan investor tetapi di lain pihak akan merugikan emiten karena dana yang dikumpulkan menjadi tidak maksimal.

Menurut Trisnawati (1999) informasi prospektus merupakan salah satu sumber informasi utama yang digunakan investor untuk memutuskan apakah berinvestasi pada emiten atau tidak di pasar modal. Prospektus, menyajikan informasi mengenai perusahaan, laporan keuangan terbaru dan historis, proyeksi laba, dan persentase dividen yang dijanjikan, analisis perbandingan dengan industri sejenis, dan tujuan penggunaan dana.

Initial Return merupakan proksi dari keputusan modal berinvestasi di pasar modal. Penelitian terdahulu menunjukan signal yang termuat dalam prospektus baik informasi keuangan maupun non keuangan yang berkenaan dengan keputusan investasi. Informasi keuangan yang menunjukkan signal dalam prospektus perusahaan terdiri dari rasio solvabilitas, rasio profitabilitas dan rasio aktivitas perusahaan. Sedangkan signal yang ditunjukkan oleh informasi non keuangan dalam prospektus perusahaan mencakup reputasi auditor dan penjamin emisi, umur perusahaan dan persentase penawaran saham saat IPO.

Investor menanamkan dananya di pasar perdana bertujuan untuk mendapatkan initial return. Yang diperoleh dari selisih harga lebih antara harga di pasar sekunder dengan harga di pasar perdananya. Harga saham perdana yang relatif lebih rendah disebabkan oleh asimetri informasi. Asimetri informasi ini dapat terjadi antara perusahaan emiten dengan perusahaan penjamin emisi.

Berawal dari adanya asimetri informasi tentang kinerja perusahaan sebelum penawaran, maka dimungkinkan terjadi initial return yang akan diperoleh investor. Hal ini akan mendorong emiten untuk melakukan perbaikan kinerja sebelum penawaran yang tercermin dalam laporan prospektusnya. Berdasarkan uraian di atas maka penulis ingin mengetahui: 1) Bagaimana profitabilitas dalam prospektus perusahaan memberikan signal terhadap initial return saham perdana; 2) Bagaimana kewajiban finansial dalam prospektus perusahaan memberikan signal terhadap initial return saham perdana; 3) Bagaimana likuiditas dalam prospektus perusahaan memberikan signal terhadap initial return saham perdana.

Tinjauan Literatur

Teori Pensignalan

Dalam teori pensignalan membahas masalah informasi asimetri di pasar. Teori ini menjelaskan bagaimana informasi asimetri dapat dikurangi dengan cara, salah satu pihak memberikan signal informasi kepada pihak lain (Morris, 1987). Manajer memiliki informasi lebih baik mengenai kondisi perusahaan dibandingkan pihak eksternal. Akibatnya pihak eksternal perusahaan yang tidak memiliki informasi lengkap akan 
memiliki persepsi yang sama tentang nilai semua perusahaan. Pandangan seperti ini akan merugikan (menguntungkan) perusahaan yang memiliki proyek investasi yang lebih baik (buruk) karena pihak eksternal akan menilai perusahaan lebih rendah (tinggi) dari yang seharusnya sehingga menimbulkan opportunity loss (opportunity gain). Perusahaan berkualitas akan meninggalkan pasar, fenomena adverse selection (Akerlof, 1970), kecuali kalau mereka dapat menginformasikan kepada pihak eksternal kualitas mereka sehingga meningkat-kan nilai perusahaan. Komunikasi ini dilakukan dengan pensignalan, yaitu mempublikasikan informasi atau signal yang dapat menggambar-kan kualitas perusahaan. Supaya efektif, signal tidak mudah ditiru oleh perusahaan lain yang memiliki kualitas yang lebih rendah.

Battacharya (2004) mendefinisikan signal sebagai suatu tindakan yang dipilih manajer yang memiliki kompetensi tinggi dimana tindakan ini tidak rasional dilakukan jika manajer tersebut memiliki kompetensi rendah. Pasar juga memiliki peran memaksa manajer sehingga termotivasi untuk menyampaikan informasi internal karena tindakan ini akan memaksimalkan nilai pasar perusahaan. Pemilihan kebijakan akuntansi juga merupakan signal, misalnya perusahaan yang memilih kebijakan akuntansi konservatif dan masih mendapatkan laba menunjukkan perusahaan berkualitas. Jika akuntansi konservatif merupa-kan signal keyakinan manajer akan nilai perusahaan di masa depan. Prakiraan yang bersifat sukarela bila dilaporkan oleh perusahaan merupakan signal positif bagi perusahaan.

Dalam kaitannya dengan kewajiban finansial, juga merupakan signal perusahaan. Perusahaan untuk memasuki pasar modal lebih sering dan harus menggunakan kondisi perusahaan ketika manajer memerlukan tambahan dana eksternal untuk operasi dan investasi. Dorongan pasar yang memotivasi manajer untuk menyampaikan informasi internal memiliki kendala karena dipengaruhi oleh berbagai faktor seperti tingkat kegagalan pasar, adanya noise trading yang akan berdampak pada ketidaktepatan harga pasar. Manajer tidak akan memilih menginformasikan suatu informasi internal bila mereka tidak yakin bahwa signal tersebut dapat dipercaya dan menunjukkan prospek yang positif bagi perusahaan karena pasar akan menilai informasi ini.

Investasi

Menurut Jones (2000), investasi merupakan kesepakatan pada pasar dana dari satu atau lebih aset yang akan diperoleh di masa yang akan datang. Investasi merupakan komitmen sejumlah dana pada masa sekarang atau beberapa periode waktu dengan maksud mendapatkan pembayaran di masa depan. Sedang investasi menurut Tandelilin (2001), investasi merupakan komitmen sejumlah dana atau sumber daya lainnya yang dilakukan pada saat ini, dengan tujuan memperoleh sejumlah keuntungan di masa yang akan datang. Dapat disimpulkan bahwa investasi adalah komitmen penggunaan uang untuk objek tertentu dengan tujuan bahwa objek tersebut selama jangka waktu investasi akan meningkat, paling tidak bertahan dan selama jangka waktu itu pula memberikan hasil pada investor.

Investasi melibatkan sejumlah dana yang ditanamkan dalam suatu aset jangka panjang pada waktu tertentu yang diharapkan dapat menghasilkan tambahan dan bagi investor. Tambahan dan ini merupakan kompensasi atau pengorbanan dari dana yang telah disimpan, tingkat inflasi dan unsur ketidakpastian.

Pasar Perdana

Pasar perdana merupakan tempat pertama penerbitan sekuritas sebelum dipasarkan atau diperjualbelikan dengan melibatkan perusahaan dan pemerintah khususnya yang berkaitan dengan aturan-aturan pemerintah meneganai pasar perdana. Terdapat dua jenis pasar perdana dalam penerbitan sekuritas baru yaitu Initial Public Offering (IPO) dan 
Seasoned New issues Equity Offerings (SEO) yang disebut juga Right Issue. IPO terjadi untuk perusahaan yang baru pertama kali menerbitkan dan menjual sekuritas-nya di pasar modal.

Beberapa karakteristik pasar perdana adalah harga saham yang telah ditentukan tidak akan berubah, pasar perdana hanya berlaku pada saat pembelian saham dan. pasar perdana memiliki batas waktu. Para investor, dapat berinvestasi saham melalui pasar perdana, yaitu ketika perusahaan pertama kali menawarkan sahamnya kepada publik ( $g o$ public). Istilah go public biasa juga disebut IPO (Initial Public Offering) atau penawaran saham perdana. Di pasar perdana, para investor langsung membeli saham dari perusahaan. Sebelum terjun atau membeli saham melalui skema IPO, investor mempelajari perusahaan tersebut agar dapat memprediksi keberhasilan investasi. Hal ini dapat dilakukan melalui prospektus yang dikeluarkan perusahaan. Di dalam prospektus terdapat informasi dari catatan keuangan historis sampai proyeksi laba dan dividen yang akan dibayarkan untuk tahun berjalan.

Periode pasar perdana meliputi periode mulai efek ditawarkan kepada investor oleh penjamin emisi melaui para agen penjual yang ditunjuk hingga penyerahan efek kepada investor. Setelah Bapepam menyatakan per-nyataan pendaftaran efektif, emiten mulai me-nyediakan prospektus lengkap untuk publik dan memuat prospektus ringkas dalam sebuah surat kabar hrian yang berbahasa Indonesia dan mempunyai peredaran nasional. Pemasangan prospektus ringkas tersebut setidaknya dilakukan 3 hari kerja sebelum masa penawaran umum dengan maksud calon investor dapat mem-pelajari terlebih dahulu penawaran emiten.

Pada masa penawaran umum, calon investor yang tertarik dapat mulai mengajukan pesanan kepada penjamin emisi melalui agen penjualan yang ditunjuk. Masa ini berlangsung selama minimal 3 hari kerja dan selesai selambat-lambatnya 60 hari setelah efektifnya pernyataan pendaftaran. Berakhirnya masa penawaran disusul dengan penjatahan efek. Penjatahan efek adalah pengalokasian efek pesanan para investor sesuai dengan jumlah yang tersedia. Jika kemudian ternyata jumlah permintaan efek selama masa Penawaran Umum melebihi jumlah efek yang ditawarkan, diadakan penjatahan khusus oleh manajer penjatahan.

SEO terjadi jika perusahaan sebelumnya pernah menerbitkan sekuritas dan sekuritas tersebut masih beredar atau diperdagangkan di pasar modal. Secara teoritis penawaran saham-saham di pasar perdana dapat mengalami overpricing atau underpricing. Pendekatan untuk menjelaskan kondisi saham ini dapat dilakukan melalui penilaian. Pertama, dengan cara menaksir harga teoritis saham-saham tersebut dan dibandingkan dengan dengan harga yang ada di pasar perdana. Jika harga di pasar perdana tinggi dari harga teoritis saham tersebut dinilai overvalue. Sebaliknya jika harga teoritis lebih rendah dari harga pasar perdana maka saham mengalami undervalue. Kedua, membandingkan tingkat keuntungan yang diperoleh dari saham-saham yang baru dijual tersebut dengan memperhatikan faktor perbedaan risiko. Jika keuntungan diperoleh lebih besar dari tingkat keuntungan yang diharapkan berarti nilai saham tersebut undervalue. Sebaliknya jika tingkat keuntungan yang diperoleh lebih kecil maka nilai saham tersebut overvalue.

Pendekatan yang digunakan dalam menganalisis harga saham perdana ini adalah dengan membandingkan antara tingkat return sesungguhnya dengan tingkat return yang diharapkan. Formulanya adalah sebagai berikut :

- Jika tingkat return sesungguhnya > return yang diharapkan maka, saham tersebut dikatakan sebagai saham yang undervalue;

- Jika tingkat return sesungguhnya < return yang diharapkan maka, saham tersebut dikatakan sebagai saham yang overvalue. 
Dengan pendekatan ini diharapkan analisa terhadap harga perdana saham di BEI dapat dilakukan dengan lebih akurat sehingga para investor lebih efektif di dalam menanamkan modalnya.

Prospektus Perusahaan

Prospektus, menyajikan informasi mengenai perusahaan, laporan keuangan terbaru dan historis, proyeksi laba, dan persentase dividen yang dijanjikan, analisis perbandingan dengan industri sejenis, dan tujuan penggunaan dana. Menurut Trisnawati (1999), prospektus merupakan salah satu sumber informasi utama yang digunakan investor untuk memutuskan apakah berinvestasi pada emiten atau di tempat lain.

Prospektus merupakan bentuk promosi emiten atas perusahaannya. Emiten akan memasukkan ke dalam prospektus informasi-informasi yang relevan dengan bisnis perusahaan sebagaimana yang disyaratkan oleh Bapepam, dengan harapan dapat menarik banyak calon pembeli berdatangan. Cara mendapatkan pros-pektus ringkas adalah melalui surat kabar harian nasional, paling tidak 3 hari kerja sebelum dimulainya masa Penawaran Umum. Sedangkan prospektus lengkap baru bisa diperoleh bersamaan dengan pengambilan surat saham kolektif di Biro Administrasi Efek. Guna menilai tawaran sebuah emiten sebelum mengambil keputusan membeli maka diperlukan prospektus ringkas.

Menurut Fama (1970) dalam Suad Husnan (2001) membagi informasi menjdi tiga tipe yaitu (1) informasi perubahan harga di waktu lalu (past price changes), (2) informasi yang tersedia kepada publik dan (3) informasi yang tersedia kepada public maupun private (public and private information).

Dalam penelitian ini informasi prospektus dapat dilihat dari beberapa variabel yang berguna bagi investor untuk menentukan pilihan investasi pada emiten tertentu. Varibel tersebut di antaranya adalah return on asset, financial leverage, current ratio, umur perusahaan.

Konsep Dasar Initial Return Saham Pada IPO

Penjualan saham perdana semasa IPO dilakukan oleh underwritter. Underwritter memberi masukan tentang prosedur dan keuangan perusahaan, membeli saham perdana dan menjualnya ke publik. Selisih antara harga beli sekuritas oleh underwritter dari emiten dengan harga penawaran disebut spread atau discount yang sekaligus merupakan kompensasi yang diterima underwritter dari penerbitan sekuritas. Bila underpricing terjadi, maka investor berkesempatan memperoleh abnormal return berupa initial return positif. Menurut Suad Husnan, 2003, abnormal return merupakan selisih antara tingkat keuntungan yang sesungguhnya dengan tingkat keuntungan yang diharapkan.

Penelitian Terdahulu

Susilowati (2006) menguji konsekuensi signal substitusi dan komplemen dalam keputusan pendanaan. Hasil penelitian menunjukkan bahwa: 1) terbukti kewajiban operasi dan kewajiban financial mempengaruhi kinerja perusahaan, 2) terbukti signal substitusi mempengaruhi keputusan pendanaan, sedangkan signal komplemen tidak terbukti mempengaruhi keputusan pendanaan.

Rina Trisnawati (1998) menguji Pengaruh informasi prospektus terhadap initial return di pasar perdana. Variabel dependen dalam penelitian tersebut adalah initial return sedang variabel independennya adalah reputasi auditor, reputasi penjamin emisi, prosentase penawaran saham saat IPO, umur perusahaan, profitabilitas perusahaan yang diukur dengan rate of return on total assets (ROA) dan financial leverage. Sampel yang digunakan adalah 47 perusahaan yang melakukan go public selama tahun 1994 dan 1995. Hasil penelitian menunjukkan bahwa hanya umur perusahaan yang berpengaruh 
signifikan dan positif terhadap initial return. Sementara variabel independen lainnya tidak mempengaruhi secara signifikan initial return.

Penelitian Fatchan Achyani (1999) memisahkan variabel penelitian antara informasi non keuangan (reputasi auditor, reputasi underwriter, umur perusahaan, prosentase penawaran dan sektor industri) dan informasi keuangan (ROA, financial leverage, ukuran perusahaan). Hasil penelitian menunjukan bahwa variabel yang berpengaruh terhadap initial return adalah informasi keuangan berupa financial leverage dan ukuran perusahaan. Informasi lain yang terkandung dalam prospektus yaitu reputasi auditor, reputasi underwriter, umur perusahaan, prosentase penawaran, sektor industri, dan profitabilitas perusahaan tidak digunakan oleh investor di pasar perdana.

Bandi, Y. Aryani dan Rahmawati (2003) meneliti peranan variabel-variabel keuangan dan varibel signaling dalam penetuan harga pasar saham saat listing hari pertama di pasar sekunder. Sampel yang digunakan adalah penawaran perdana pada tahun 1994 sampai dengan tahun 1996 yaitu sebanyak 68 perusahaan. Variabel dependen adalah harga saham sesudah IPO. Sedang variabel independen adalah laba per lembar saham, ukuran penawaran, tipe-tipe penawaran saham, indeks saham, kualitas underwriter, proceeds, financial leverage dan ROA. Teknik analisis statistik yang digunakan untuk menganalisis data adalah model regresi. Hasilnya menunujukan variabel laba per lembar saham dan junlah saham yang ditawarkan berpengaruh signifikan sedang indeks saham tidak berpengaruh pada harga saham.

Misnen Ardiansyah (2004) menguji pengaruh variabel keuangan dan non keuangan terhadap initial return saham. Sampel yang digunakan adalah perusahaan yang melakukan IPO tahun 1995 sampai dengan tahun 2001 yang dipilih berdasarkan purposive sampling, yaitu sebanyak 64 perusahaan. Varaibel dependen terdiri dari return awal dan return 15 hari setelah IPO, sedang variabel independent adalah rate of return on total assets / ROA, financial leverage / FL, earnings per share / EPS, proceeds, pertumbuhan laba, dan current ratio / CR sebagai variabel utama sedangkan umur perusahaan, reputasi penjamin emisi, reputasi auditor, jenis industri dan kondisi perekonomian sebagai variabel pengontrol. Hasil uji-t menunjukan bahwa hanya variabel earnings per share / EPS signifikan 5\% terhadap initial return. Variabel keuangan yang lain ROA, financial leverage, proceeds, pertumbuhan laba, dan current ratio tidak signifikan. Sedang variabel non keuangan menunjukan hanya kondisi perekonomian yang signifikan pada level 0,006 terhadap initial return dan variabel-variabel lain tidak berpengaruh signifikan terhadap initial return.

Suyatmin dan Sujadi (2006), menguji pengaruh variabel-variabel keuangan dan non keuangan terhadap underpricing saham pada penawaran umum perdana di Bursa Efek Jakarta. Variabel keuangan tersebut adalah ROI, Financial Leverage, Laba Per Saham, Proceeds dan Current Ratio. Sedang variabel non keuangan yang digunakan adalah besaran perusahaan, umur perusahaan, reputasi auditor, reputasi underwritter dan jenis industri. Sampel yang digunakan adalah perusahaan yang go public pada periode 1999 s.d 2003 dengan ketersediaan data lengkap sehingga diperoleh sampel sebanyak 49 emiten. Hasil uji-t menunjukkan bahwa pengaruh variabel keuangan terhadap underpricing saham menunjukkan hanya variabel current ratio bernilai signifikan sebesar 0,010 . Variabel keuangan lainnya seperti besaran perusahaan, ROI, Financial Leverage, PER dan Proceeds tidak signifikan. Sedang uji-t pengaruh variabel non keuangan terhadap underpricing saham menunjukkan bahwa umur perusahaan, reputasi auditor, jenis industri dan reputasi underwritter berpengaruh signifikan terhadap underpricing saham. Hasil ini menujukan bahwa investor menggunakan informasi non keuangan emiten ketikan berinvestasi di pasar perdana. 


\section{Model Analisis Konseptual Penelitian}

Model analisis konseptual dalam penelitian ini berusaha mengkaitkan teori pensignalan dalam konteks keputusan investasi yang secara spesifik difokuskan pada informasi prospektus perusahaan terutama variabel keuangan terhadap initial return saham di pasar perdana sebagai cara yang dipilih manajemen sebagai signal yang akan disampaikan atau diinformasikan kepada pasar. Gambar 1 menyajikan bentuk hubungan profitabilitas, kewajiban financial dan likuiditas sebagai bentuk signal yang relevan untuk diinformasikan di pasar agar supaya investor dapat memprediksi initial return pada saat penawaran saham perdana dapat digambarkan dalam bagan berikut:

Gambar 1

Model Analisis Konseptual Penelitian

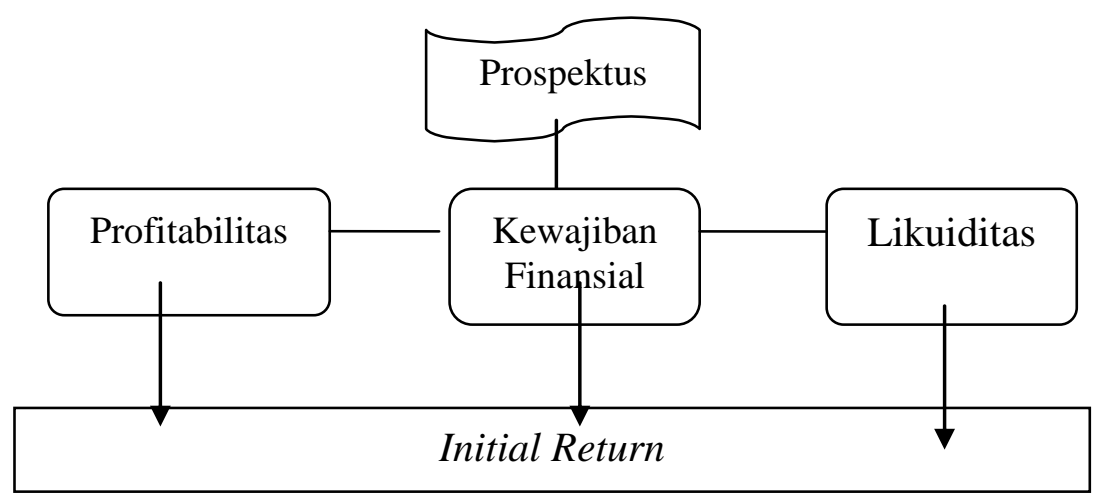

\section{Hipotesis}

1. Profitabilitas dengan Initial Return

Variabel keuangan dalam prospektus perusahaan akan memberi signal penting bagi calon investor untuk menanamkan sahamnya di pasar perdana. Profitabilitas merupakan kemampuan emiten untuk menghasilkan keuntungan dan mengukur tingkat efisiensi operasional dan efisiensi dalam menggunakan harta yang dimilikya.

Profitabilitas suatu perusahaan yang mencerminkan efektifitas operasional perusahaan untuk mendapatkan laba di masa datang. Apabila profitabilitas suatu perusahaan bernilai tinggi maka akan mengurangi risiko ketidakpastian bagi investor. Penggunaan profitabilitas mencerminkan keyakinan manajemen tentang kemampuan perusahaan untuk memperoleh keuntungan yang cukup dimasa datang. Dengan kata lain, peningkatan profitabilitas merupakan signal positif bahwa untuk mendapatkan keuntungan di masa datang lebih tinggi daripada ketidakpastian atau risiko yang dihadapi perusahaan. Oleh karena itu profitabilitas diprediksi berpengaruh positif terhadap initial return (Kim et. Al., 1993 dan Misnen Ardiansyah, 2004)

$\mathrm{H}_{1}$ : Profitabilitas berpengaruh positif terhadap initial return

2. Kewajiban Finansial dengan Initial Return

Kewajiban finansial merupakan sumber pendanaan (utang) berbeban bunga yang pada umumnya digunakan untuk membiayai aset tetap/ jangka panjang. Kewajiban finansial mencerminkan kepercayaan pasar tehadap peru-sahaan. Dari sudut pandang teori pensig-nalan, selain sebagai indikator kepercayaan pasar, penggunaan kewajiban finansial mencerminkan keyakinan manajemen tentang kemampuan perusahaan untuk memperoleh aliran kas yang cukup dimasa datang 
lebih besar dari kewajiban finansialnya. Dengan kata lain, peningkatan kewajiban finansial merupakan signal positif bahwa untuk mendapatkan keuntungan di masa datang lebih tinggi daripada ketidakpastian atau risiko yang dihadapi perusahaan. Oleh karena itu kewajiban finansial diprediksi berpengaruh terhadap initial return (Daljono, 2000; Kim et. al., 1995; Trisnawati, 1998).

$\mathrm{H}_{2}$ : Kewajiban finansial berpengaruh positif terhadap initial return

\section{Likuiditas dengan Initial Return}

Semakin likuid suatu perusahaan berarti semakin kecil risiko kegagalan perusahaan dalam memenuhi kewajiban jangka pendeknya. Sehingga risiko yang akan ditanggung oleh pemegang saham juga semakin kecil. Dengan kata lain, peningkatan likuiditas merupakan signal positif bahwa untuk mendapatkan keuntungan di masa datang lebih tinggi daripada ketidakpastian atau risiko yang dihadapi perusahaan. Oleh karena itu likuiditas diprediksi berpengaruh terhadap initial return. (Misnen Ardiansyah, 2004)

$\mathrm{H}_{3}$ : Likuiditas berpengaruh positif terhadap initial return

\section{METODE PENELITIAN}

Populasi yang digunakan dalam penelitian ini adalah semua perusahaan yang telah go public di Bursa Efek Indonesia periode tahun 2002 sampai dengan tahun 2006. Total perusahaan yang melakukan IPO pada periode tersebut sebanyak 60 perusahaan. Pengambilan sampel dengan menggunakan metode purposive sampling yaitu teknik penentuan sampel dengan pertimbangan tertentu. Kriteria yang digunakan untuk pemilihan sampel dalam penelitian ini adalah sebagai berikut :

1. Perusahaan non keuangan yang go public selama periode 2002 sampai dengan 2006 di Bursa Efek Indonesia;

2. Tanggal listing dan harga penawaran tersedia;

3. Laporan keuangan yang digunakan adalah laporan keuangan yang tercantum dalam Prospektus Perusahaan pada saat perusahaan go public;

4. Data harga penutupan (closing price) yang tersedia di Pojok BEI

Penelitian ini menggunakan data sekunder yang diperoleh dari perusahaan non keuangan go public di Indonesia yang diperoleh dari Indonesian Capital Market Directory. Jenis data yang digunakan dalam penelitian ini adalah data kuantitatif, dinyatakan dalam rasio keuangan yang menunjukkan besaran variabel yang mewakilinya. Adapun data dan variabel keuangan yang digunakan dalam penelitian ini adalah sebagai berikut :

1. Harga perdana saham perusahaan non keuangan yang melakukan IPO di BEI pada periode tahun 2002 sampai dengan tahun 2006;

2. Harga penutupan saham, saat diperdagang-kan pertama kali di pasar sekunder pada periode tahun 2002 sampai dengan tahun 2006;

3. Neraca keuangan perusahaan non keuangan yang melakukan IPO dan listing di BEI periode tahun 2002 sampai dengan tahun 2006;

4. Laporan Rugi Laba perusahaan non keuangan yang melakukan IPO dan listing di BEI periode tahun 2002 sampai dengan tahun 2006. 


\section{Definisi Operasional Variabel}

Penelitian ini menggunakan variabel dependen dan variabel independen. Variabel independen (X) ini merupakan rasio keuangan yang diduga akan mempengaruhi investor membeli saham perdana dengan harapan memperoleh initial return. Variabel independen ini terdiri dari :

1. Profitabilitas

Profitabilitas mencerminkan kemampuan perusahaan untuk mendapatkan keuntungan operasi. Tingkat keuntungan ini ditentukan berdasarkan laba akuntansi yang dapat dihitung dengan rumus sebagai berikut:

$$
\mathrm{ROA}=\frac{\text { Net Income After Tax }}{\text { Total Asset }} \times 100 \%
$$

2. Kewajiban Finansial

Debt To Equity merupakan salah satu rasio dari kewajiban finansial. Pengertian kewajiban finansial adalah penggunaan dana untuk perusahaan guna membayar return tetap atas penggunaan dana utang. Dalam bahasa terminologi financial leverage yang besar berarti mengungkit yang kecil dalam penjualan mengakibatkan perubahan yang besar dalam tingkat laba. Para kreditur memperhatikan equity dalam batas keamanan, akan tetapi dengan betambahnya utang para pemilik memperoleh manfaat yakni dapat mempertahankan pengendalian atas perusahaan dengan investasi yang terbatas. Debt To Equity merupakan per-hitungan sederhana yang membandingkan total utang perusahaan dengan modal pemegang saham. Dengan demikian debt to equity ratio dapat memberikan gambaran mengenai struktur modal yang dimilki perusahaan sehingga dapat dilihat risiko tak terbayarkan suatu utang. Secara formula debt to equity ditulis seperti berikut:

$$
\text { Total Debt }
$$

Debt To Equity $=\frac{\text { Total Equity }}{* 100 \%}$

\section{Likuiditas}

Current Ratio merupakan ukuran likuiditas suatu perusahaan.. Variabel ini merupakan rasio utang lancar dengan terhadap aktiva lancar. Hubungan antara return dengan likuiditas (current ratio) akan dipengaruhi oleh business cycle. Secara intuitif, besarnya likuiditas akan mengurangi jumlah utang yang tidak dapat dibayar, maka seharusnya return berhubungan positif dengan business cycle. Perusahaan dengan fundamental yang kuat akan tergantung pada dana internalnya sedangkan perusahaan dengan fundamental lemah akan tergantung pada dana eksternal. Secara formula current ratio ditulis:

$$
\text { Current Ratio }=\frac{\text { Current Debt }}{\text { Current Asset }} \times 100 \%
$$

Sedangkan variabel dependen (Y) dalam penelitian ini adalah initial return. Initial return merupakan selisih antara harga penawaran umum (offering price) dengan harga penutupan di pasar sekunder pada hari pertama (closing price) dikali dengan $100 \%$. Secara matematis, initial return ditulis : 
(closing price) - (offering price)

Initial Return $=$

$\mathrm{x} 100 \%$

Model Penelitian

offering price

Penelitian ini menggunakan metode explanatory survey yaitu metode yang bertujuan untuk menjelaskan hubungan antar variabel. Analisis yang digunakan adalah analsis deskriptif untuk menginterpretasikan data-data berdasarkan faktafakta yang terlihat dalam kurun waktu pengamatan. Penelitian dimulai dari teori sebagai titik awalnya, selanjutnya data-data yang diperoleh selama penelitian akan diolah, dianalisis dan diuji. Hasil pengujiaan akan menghasilkan kesimpulan berdasarkan teori yang telah berlaku. Pengujian penelitian ini menggunakan analisis Regresi Berganda (Multiple Regression) untuk menerangkan akibat langsung dan tidak langsung seperangkat variabel. Dalam menguji dan menganalisis digunakan bantuan software program SPSS.

Setelah ditentukan variabel dependen dan independen yang akan diuji, selanjutnya adalah menentukan metode penelitian yang akan menjelaskan hubungan antara variabel dependen dan independen. Pengujian tersebut menggunkan Analisis Regresi Linear Berganda. Analisis Regresi Berganda menyangkut hubungan antara variabel dependen (Y) dengan dua atau lebih variabel independen $(\mathrm{X})$. Bentuk rumusan model penelitian ini adalah sebagai berikut :

dimana :

$$
I_{t}=\beta o+\beta_{1} P_{t-1}+\beta_{2} K_{t-1}+\beta_{3} L_{t-1}+e
$$

IR : initial Return

$\mathrm{P}$ : profitabilitas

$\mathrm{KF}$ : kewajiban finansial

L : likuiditas

Bo : bilangan konstan

$\beta_{1}, \beta_{2}, . . \quad$ : koefisien arah regresi untuk variable bebas

Untuk menaksir fungsi regresi populasi atas dasar regresi sampel akan digunakan metode Pengujian Ketepatan Perkiraan (Uji $\mathrm{R}^{2}$ ). Pengujian ini dilakukan untuk mengetahui seberapa besar keterkaitan variabel initial return terhadap variabel dependennya. Besarnya $\mathrm{R}^{2}$ (coefficient of determination) yang digunakan adalah nilai $\mathrm{R}^{2}$ yang telah memperhitungkan jumlah variabel independen dalam model regresi atau lebih dikenal dengan Adjusted $\mathrm{R}^{2}$. Penerapan metode ini mempunyai beberapa asumsi :

1. Terdapat hubungan linear antar variabel;

2. Data bersumber dari populasi berdistribusi normal;

3. Tidak ada autokorelasi;

4. Tidak terdapat multikolinearitas;

5. Tidak terdapat heteroskedastisitas

Pengujian Hipotesis

Uji Koefesien Regresi Parsial (Uji t)

Uji t menunjukkan seberapa besar konsekuensi signal satu variabel independen secara individual dalam menerangkan variasi variabel dependen. 
Apabila signifikan, maka variabel independen mempunyai konsekuensi signal parsial terhadap variabel dependen. Penetuan uji-t dalam penelitian ini menggunakan alat bantu SPSS, dengan melihat nilai level of significance $(\alpha)=\%$. Kriteria penentuannya adalah sebagai berikut :

1. Ho diterima, apabila nilai sig. $<5 \%$

2. Ho ditolak, apabila nilai sig $>5 \%$

Uji Fit Model (Uji F)

Uji menunjukan apakah semua variabel independen yang dimasukkan dalam model secara bersama-sama mempunyai pengaruh terhadap variabel dependen initial return. Langkah-langkah yang ditempuh dalam Uji $\mathrm{F}$ adalah:

1. Menentukan $\mathrm{H}_{0}$ dan $\mathrm{H}_{1}$

Ho : $\beta 1, \beta_{2}, \ldots=0$ artinya tidak ada pengaruh variabel independent terhadap variabel dependen

Ho : $\beta 1, \beta 2, \ldots \neq 0$ artinya ada pengaruh variabel independent terhadap variabel dependen;

2. Menentukan level of significance $\alpha=5 \%$;

3. Menentukan kriteria pengujian

$\mathrm{F}$ hitung < F tabel maka Ho diterima artinya variabel independen secara sendiri-sendiri tidak berpengaruh terhadap initial return

$\mathrm{F}$ hitung > F tabel maka Ho ditolak artinya variabel independen secara sendiri-sendiri berpengaruh terhadap initial return;

4. Menentukan daerah penerimaan dengan menggunakan distribusi F;

5. Menentukan nilai statistik Uji F ratio.

\section{PEMBAHASAN}

Pembahasan diawali dengan melakukan pengujian hipotesis dengan meregresikan variabel yang meliputi return on asset, total debt to equity, dan current ratio terhadap initial return. Pengujian dilakukan dengan menggunakan SPSS 13, melalui enter data variabel-variabel tersebut dan menganalisanya menggunakan regresi linear berganda dengan degree of freedom (df) $95 \%$ serta tingkat error sebesar 5\% (100\%-df). Beberapa pengujian yang dilakukan adalah sebagai berikut:

Pengujian Regresi Parsial (Uji t)

Uji $\mathrm{t}$ pada dasaranya menunjukan seberapa jauh pengaruh variabel independen secara individual dalam menerangkan variasi variabel dependen. Langkah-langkah dalam menentukan uji $t$ melalui alat bantu SPSS. Hasil pengolahan data SPSS, diperoleh model regresi berganda yang terbentuk pada penelitian dapat diformulasikan sebagai berikut :

$\mathrm{IR}=-2,406+0,003 \mathrm{P}+1,013 \mathrm{KF}+1,985 \mathrm{~L}+\mathrm{e}$ 
Tabel 1.

Hasil Pengujian Hipotes Dengan Uji-t

\begin{tabular}{|l|c|c|c|}
\hline \multicolumn{1}{|c|}{ Variabel } & $\boldsymbol{\beta}$ & Std.Error & Prob-value (sig) \\
\hline Konstanta & $-2,406$ & 2,274 & 0,307 \\
\hline Profitabilitas (ROA) & 0,003 & 0,185 & 0,987 \\
\hline Kewajiban Finansial (DTE) & 1,013 & 0,639 & 0,134 \\
\hline Likuiditas (CR) & 1,985 & 0,727 & 0,015 \\
\hline
\end{tabular}

Sumber : Hasil Perhitungan

Untuk mengetahui tingkat signifikansi dari masing-masing variabel bebas terhadap variabel terikat dengan menggunakan uji t adalah sebagai berikut :

1. Variabel Profitabilitas (ROA) pada $\alpha=5 \%$ tidak memberikan konsekuensi signal yang signifikan terhadap initial return, karena tingkat signifikansinya terjadi pada Probabilitas value 0,987 ;

2. Variabel Kewajiban Finansial (Debt To Equity) pada $\alpha=5 \%$ tidak memberikan konsekuensi signal yang signifikan terhadap initial return karena tingkat signifikansinya terjadi pada Probabilitas value 0,134;

3. Variabel Likuiditas (Current Ratio) perusahaan pada $\alpha=5 \%$ memberikan konsekuensi signal yang signifikan terhadap initial return, karena tingkat signifikansinya terjadi pada nilai Probabilitas 0,015 .

Hasil pengujian menunjukkan bahwa variabel Likuiditas (current ratio) memberikan konsekuensi signal secara signifikan terhadap initial return. Koefisien variabel tersebut bertanda positif dan secara statistik signifikan pada alpha di bawah 5\%. Hasil ini tidak ditemukan pada penelitian-penelitian yang dilakukan oleh Suyatmin dan Sujadi, (2001). Signifikansi variabel likuiditas mengindikasikan bahwa likuiditas dapat memberikan konsekuensi signal kepada pihak luar perusahaan mengenai efektivitas operasional perusahaan, dimana likuiditas yang tinggi menjadi perhatian investor untuk menentukan keputusannya di pasar perdana. Investor beranggapan bahwa pada perusahaan non keuangan peran likuiditas perusahaan teramat penting, mengingat perusahaan jenis ini masalah aktiva lancar menjadi berperan. Semakin tinggi likuiditas suatu perusahaan berarti semakin kecil pula risiko kegagalan perusahaan dalam memenuhi kewajiban jangka pendeknya. Dengan kata lain berarti risiko yang akan ditanggung investor pun akan menjadi kecil pula. Jadi semakin tinggi current ratio berarti semakin tinggi juga initial return saham yang akan diperoleh.

Likuiditas yang tinggi dicerminkan dengan nilai current rasio yang besar artinya perusahaan mempunyai kemampuan yang besar untuk menutupi kewajiban lancarnya. Secara umum, jika perusahaan memiliki likuiditas yang tinggi berarti perusahaan memilih menahan dananya ke dalam bentuk-bentuk aset lancar dibanding memanfaatkan untuk pengembangan usaha. Namun secara khusus, setiap perusahaan memiliki karakteristik sendiri dalam menentukan current rationya. Perusahaan manufaktur akan mengambil policy untuk memperbesar likuiditas. Hal ini diperlukan untuk menjaga perusahaan agar tidak mengalami kebangkrutan akibat kekurangan likuiditas jika terjadi resesi ekonomi.

Variabel independen lainnya yaitu Profitabilitas (ROA) menunjukan hasil yang tidak signifikan terhadap initial return saham. Variabel profitabilitas memiliki nilai sig. sebesar 0,987. Hasil ini sesuai dengan penelitian yang 
dilakukan oleh Rina Trisnawati pada tahun 2006. Artinya profitabilitas khususnya ROA kurang digunakan oleh investor dalam pasar perdana, mereka beranggapan bahwa pada perusahaan manufaktur, keberadaan aset tetap lebih dipentingkan. Mengingat apabila terjadi kondisi likuidasi perusahaan, investor masih dapat meminimalisasi risiko. Paradigma sebalik-nya terjadi pada perusahaan keuangan, investor akan lebih memperhatikan return perusahaan. Mengingat dalam laporan keuangan perusahaan yang lebih menonjol adalah aset lancarnya.

Sedangkan hasil pengujian variabel kewajiban finansial (Debt To Equity) menunjukan nilai t hitung sebesar 1,585 serta signifikansi sebesar 0,143 . Variabel total kewajiban finansial tidak berpengaruh secara signifikan terhadap initial return karena secara statistik tingkat signifikannya $>5 \%$. Artinya variabel kewajiban finansial tidak berpengaruh signifikan terhadap initial return saham. Atau dengan kata lain hipotesis yang menduga informasi keuangan dari prospektus perusahaan berupa kewajiban finansial mempunyai pengaruh secara signifikan terhadap initial return ditolak atau tidak terbukti kebenarannya.

Hasil ini sesuai dengan penelitian yang dilakukan oleh Rina Trisnawati (2006), dan Misnen Ardiansyah (2004) yang menyimpulkan bahwa variabel keuangan berupa financial leverage memberikan konsekuensi signal tidak signifikan terhadap initial return saham. Fluktuasi bisnis perusahaan berdampak besar terhadap keuntungan pemilik ekuitas, bila sebagian modal perusahaan dibiayai oleh hutang. Oleh karena itu kewajiban finansial merupakan ukuran resiko perusahaan. Hasil ini konsisten dengan teori risk dan return yang berasumsi bahwa semakin tinggi risiko suatu perusahaan maka investor menginginkan return yang tinggi bila berinvestasi pada perusahaan tersebut. Kewajiban finansial merupakan informasi akuntansi yang memberikan konsekuensi signal terhadap keputusan investasi. Keputusan yang akan diambil berhubungan dengan besarnya dana yang harus dikeluarkan dan risiko yang akan ditanggung dalam investasi. Dalam penelitian ini investor beranggapan bahwa nilai risiko kewajiban finansial sebesar rata-rata 1,39 tidak sebanding dengan perolehan return yang diharapkan. Sehingga variabel kewajiban finansial kurang memberikan konsekuensi signal terhadap keputusan investor untuk bertransaksi di pasar perdana.

Pengujian Fit Model

1. Uji F

Uji $F$ pada dasarnya menunjukkan apakah semua variabel bebas/independen yang dimasukkan dalam model mempunyai pengaruh secara bersama-sama terhadap variabel dependen. Berikut ditampilkan hasil pengolahan data melalui alat bantu SPSS :

Tabel 2.

Hasil Pengujian Hipotes Dengan Uji-F

\begin{tabular}{|l|c|c|c|}
\hline \multicolumn{1}{|c|}{ Model } & df & F & Prob-value (sig) \\
\hline Regresi & 3 & 2,630 & 0,088 \\
\hline Residual & 15 & & \\
\hline Total & 18 & & \\
\hline
\end{tabular}

Sumber : Hasil Perhitungan

Hasil uji signifikansi serentak menghasil-kan angka 0,088 yang berarti variabel Profitabilitas, Kewajiban Finansial dan Likuiditas memberikan 
konsekuensi signal serentak terhadap initial return saham dengan kriteria marginal signifikan. Hal ini didasarkan pada tingkat signifikansi uji $\mathrm{F}$ berada di bawah 0,1 sehingga masuk dalam kategori marginal signifikan.

Variabel profitabilitas dapat memberikan konsekuensi signal kepada pihak luar perusahaan mengenai efektivitas operasional perusahaan, dimana profitabilitas yang tinggi menunjukkan kemampuan perusahaan untuk menghasilkan laba juga tinggi. Profitabilitas yang tinggi akan menarik lebih banyak investor untuk melakukan investasi sehingga permintaan akan saham perusahaan meningkat. Akibatnya harga saham akan naik dan perubahan harga di antara transaksi yang terjadi semakin kecil. Laba merupakan informasi penting bagi investor untuk pengambilan keputusan investasi. Namun dalam perusahaan non keuangan, jumlah aset tetap menjadi perhatian tersendiri bagi investor.

Kewajiban finansial perusahaan merupakan kemampuan perusahaan dalam melunasi semua kewajiban dengan modal yang dimilikinya. Kreditur lebih menyukai rasio utang yang rendah karena semakin rendah rasio ini, maka semakin besar perlindungan terhadap kerugian kreditur dalam peristiwa likuidasi. Hasil penelitian menunjukkan rata-rata kewajiban finansial perusahaan memiliki tingkat yang tinggi.

Umumnya perusahaan melakukan pinjaman tinggi karena penggunaan utang akan mengurangkan laba setelah pajak sehingga dari sudut pandang manajemen ini akan menguntungkan perusahaan karena ada penghematan pajak. Pemegang saham akan menginginkan leverage yang lebih besar karena akan dapat meningkatkan laba yang diharapkan. Kondisi tersebutlah yang mengakibatkan kewajiban finansial kurang mempengaruhi keputusan investasi. Karena jika perusahaan mampu menghasilkan kas relatif terhadap pengeluaran kas cukup tinggi, situasi itu dapat membuat risiko solvabilitas perusahaan cukup rendah.

Informasi yang lain di dalam prospektus terutama informasi non keuangan kurang diperhatikan oleh investor. Hal ini mungkin terjadi karena para investor lebih mengutamakan informasi di luar prospektus atau dapat pula emiten melakukan investasi di pasar perdana untuk kegiatan spekulasi untuk mendapatkan initial return. Namun demikian secara total faktor-faktor tersebut memberikan konsekuensi signal secara signifikan terhadap initial return. Hal ini disebabkan secara empiris faktor dilapangan, investor akan melakukan investasi terhadap perusahaan, jika investor melihat adanya underpricing, karena investor berkesempatan untuk memperoleh abnormal return berupa initial return positif.

2. Pengujian Ketepatan Perkiraan (Uji R²)

Pengujian ini dilakukan untuk me-ngetahui seberapa besar keterikatan atau keteratan variabel dependennya (initial return) dari variabel independennya. Koefisien korelasi berganda $\left(\mathrm{R}^{2}\right)$ telah memperhitungkan jumlah variabel independen dalam suatu model regresi atau disebut $\mathrm{R}^{2}$ yang telah disesuaikan (adjusted $\mathrm{R}^{2}$ ). Langkah-langkah untuk menetukan uji ketepatan adalah menggunakan perhitungan adjusted $\mathrm{R}^{\mathbf{2}}$ tersebut. Berikut ditampilkan hasil pengolahan data menggunakan SPSS : 
Tabel 3

Hasil Pengujian Hipotes Uji R ${ }^{2}$

\begin{tabular}{|l|c|c|c|}
\hline \multicolumn{1}{|c|}{ Model } & R square & Adjusted $\mathbf{R}^{2}$ & Standar Error Estimate \\
\hline Regresi & 0,345 & 0,214 & 3,40877 \\
\hline
\end{tabular}

Predictors : (constant) DTE, ROA, CR

Sumber : Hasil Perhitungan

Hasil regresi variabel keuangan terlihat bahwa besarnya $\mathrm{R}$ square 0,345 dan adjusted $\mathrm{R}^{2}$ adalah 0,214 . Hal ini berarti bahwa $21,4 \%$ initial return saham bisa dijelaskan oleh ketiga variabel keuangan yaitu return on asset, current ratio dan debt to equity. Sisanya sebesar $77,6 \%$ dijelaskan oleh variabel-variabel di luar model penelitian. Mengingat dalam berinvestasi, banyak sekali faktor-faktor yang memberikan konsekuensi signal diantaranya adalah variabel non keuangan dalam prospektus perusahaan. Termasuk hal di luar kondisi perusahaan emiten adalah kondisi makro ekonomi Indonesia, keadaan politik dan kebijakan pemerintah di bidang hukum. Namun secara umum, berdasarkan tabel 4.8 dan uji model menunjukkan bahwa investor menggunakan informasi keuangan prospektus perusahaan sebelum berinvestasi di pasar perdana.

\section{PENUTUP}

1. Hasil pengujian hipotesis secara parsial menunjukkan bahwa dalam Informasi keuangan dari laporan Prospektus Perusahaan berupa Likuiditas (Current Ratio) berpengaruh secara signifikan terhadap initial return saham perusahaan non keuangan pada saat IPO periode tahun 2002-2006. Hasil ini menunjukkan bahwa investor lebih menilai kemampuan perusahaan dalam memenuhi kewajiban jangka pendeknya. Semakin tinggi current ratio perusahaan berarti semakin kecil juga risiko kegagalan perusahaan dalam memenuhi utang lancarnya. Sehingga kemungkinan risiko yang akan ditanggung investor pun juga akan semakin minimal;

2. Hasil pengujian hipotesis secara parsial juga menunjukkan bahwa dalam Informasi prospektus berupa Profitabilitas (Return On Asset) dan Kewajiban Finansial (Debt To Equity) memberikan konsekuensi signal tidak signifikan terhadap saham perusahaan non keuangan pada saat IPO periode tahun 2002-2006. Hasil ini menunjukkan bahwa pinjaman tinggi yang dilakukan perusahaan tidak mempengaruhi keputusan investor untuk bertransaksi di pasar perdana mengingat perusahaan non keuangan cenderung lebih mapan dalam hal pengelolaan aset tetapnya;

3. Hasil pengujian hipotesis secara bersama-sama (uji F) menunjukan bahwa variabel keuangan berpengaruh marginal signifikan terhadap Initial Return perusahaan non keuangan pada saat IPO periode tahun 2002-2006.

Hasil pengujian model ini menunjukkan bahwa Informasi prospektus merupakan salah satu sumber informasi yang relevan dan dapat digunakan untuk menilai perusahaan dan membuat keputusan investasi. Informasi prospektus memberikan gambaran kinerja keuangan perusahaan yang merupakan informasi penting bagi investor untuk pengambilan keputusan investasi. Kinerja keuangan yang baik akan menarik lebih banyak investor untuk melakukan investasi sehingga permintaan akan saham perusahaan meningkat. 


\section{DAFTAR PUSTAKA}

Afriyeni, A., \& Marlius, D. (2019). Analisis Pengaruh Harga Saham Perdana Terhadap Abnormal Return Yang Diterima Investor Studi Pada Bursa Efek Indonesia. https://doi.org/10.31219/osf.io/8z7hx

Agrawal, Anup dan CR. Knoeber, 1996, Supplier Relationship and Small Business use of Trade Credit, Working Paper of University of Chicago

Akerlof, Geoge A, Tehe, Market for Lemons: Quality Uncertainty and Market Mechanisms to Control Agency Problem between Manager and Shareholders, Journal of Financial and Quantitative Analysis, September, 377-397.

Bandi Y dan Aryani Rahmawati, 2003, Peranan Variabel Keuangan Dalam Penentuan Harga Pasar Saham Perusahaan Sesudah Penawaran Umum Perdana, SNA VI Oktober Surabaya

Battacharya, Utpal, Amy Dittmar, 2004, Costless versus Costly signaling Theory and Evidence, Working paper of Boston University Alabama

Fatchan Achyani, 1999, Analisis Informasi Prospektus Yang Berpengaruh Terhadap Return Awal Penawaran Perdana Di BEJ Jurnal Ekonomi Dan Bisnis Indonesia Vol. 12 No. 2,

Husnan, Suad, Dasar-Dasar Teori Portofolio, Edisi Ketiga, Yogyakarta, UPP AMP YKPN, 2001.

Indonesian Capital Market Directory (ICMD), 2008, 13th edition, ECFIN, BEJ

Jogiyanto, H.M, 2000. Teori Portofolio Dan Analisis Investasi. BPFE, Yogyakarta. Edisi Kedua

Jones, Charles P, Investment : Analysis and Management, Ed. $7^{\text {th }}$, New York, John Wiley \& Sons, 2000

Kartini Payamta, 2002, Analisis Perilaku Harga Saham Dan Faktor-faktor Yang Mempengaruhinya Pada Penawaran Perdana Di BEJ, SNA V Semarang

Kep. Bapepam, 2000. Pedoman Mengenai Isi Dan Bentuk Prospektus Dalam Rangka Penerbitan Hak Memesan Efek Terlebih Dahulu. Jakarta, Maret

Luciana Spica Almilia dan Meliza Silvy, 2003. Anlisis Faktor-faktor Yang Mempengaruhi Status Perusahaan Pasca IPO Dengan Menggunakan Tehnik Analisis Multinomial Logit. Jurnal Ekonomi Dan Bisnis Indonesia Vol. 18 No. 4, Oktober

Luciana Spica Almilia M. Si, SE, 2006. Reaksi Pasar Dan Efek Intra Industri Pengumuman Financial Distress. Jurnal Ilmiah Bidang Ilmu Ekonomi Vol. 1 No. 1, April 
Misnen Ardiansyah, 2004, Pengaruh Variabel Keuangan Terhadap Return Awal Dan Return 15 Hari Setelah IPO Serta Moderasi Besaran Perusahaan Terhadap Hubungan Antara Variabel Keuangan Dengan Return awal Dan Return 15 Hari Setelah IPO di BEJ, Jurnal Bisnis dan Ekonomi Vol 9, No 2

Muslim Tampubolon, FX. Supriyono dan Budiana Gomulya, 2002. Kinerja Return Jangka Panjang Investasi Saham BUMN Dan Non BUMN Pada Pasar Perdana Di BEJ. USU Digital Library

Nurhidayati dan Indriantono, 1998, Analisis Faktor-Faktor Yang Berpengaruh Terhadap Tingkat Underpriced Pada Penawaran Perdana Di BEJ, Jurnal Bisnis dan Ekonomi Vol 6, No 2

Rina Trisnawati, 2006, Pengaruh Informasi Prospektus Terhadap Return Saham di Pasar Perdana,SNA IX, 2007

Susilowati, Yeye, 2006, Signal Substitusi dan Komplemen Dalam Keputusan Pendanaan, Disertasi UGM Yogyakarta

Suyatmin dan Sujadi, 2006. Faktor-faktor Yang Mempengaruhi Underpricing Pada Penawaran Umum Perdana Di Bursa Efek Jakarta (Studi Kasus Di BEJ Periode ). Jurnal Manajemen Dan Bisnis Vol. 10 No. 1, Juni 2006 : 11-32 